\title{
Javanese Women Hybridity: Postcolonial Study of Nyonya Muluk in Damar Kurung Paintings
}

\author{
Aniendya Christianna \\ Visual Communication Design, Faculty of Art and Design, \\ Petra Christian University Surabaya, Indonesia \\ E-mail: aniendya@petra.ac.id
}

\begin{abstract}
Damar Kurung is a typical lantern of Gresik, made in the 16th century. In 2017 Damar Kurung was declared an intangible cultural heritage by the Indonesian Ministry of Education and Culture. Masmundari (1904-2005) was a female artist who painted Damar Kurung based on skills learned from her ancestors. Among Masmundari's many paintings, Nyonya Muluk is the most frequently painted. Nyonya Muluk is described as a big woman wearing a dress and wings. Many people say that Nyonya Muluk is a picture of Queen Wilhemina that Masmundari has seen directly. To uncover Nyonya Muluk's identity, it is necessary to explain the image and meaning of this traditional art, the author uses Bahasa Rupa method (Tabrani, 2012), which analyzes the contents of the wimba, cara wimba, tata ungkapan and how to read wimba. Then, analyzed using postcolonial theory, specifically using the concepts of hybridity and mimicry to find out the identity of Nyonya Muluk. Finally, this research is to produce (1) A description of the relationship between the two cultures (East and West/invaders and colonized) which is manifested in the figure of Nyonya Muluk. (2) Nyonya Muluk is a representation of Javanese women's hybridity that illustrates the hopes and dreams of Masmundari (as an East representative) to be similar to the West.
\end{abstract}

Keywords: damar kurung, nyonya muluk, women, postcolonial, hybridity

\section{Hibriditas Perempuan Jawa: Studi Poskolonial Figur Nyonya Muluk Di Lukisan Damar Kurung}

\begin{abstract}
ABSTRAK
Damar Kurung adalah lentera khas Gresik, dibuat pada abad ke-16. Pada 2017 Damar Kurung dinyatakan sebagai warisan budaya tak bendawi oleh Kementerian Pendidikan dan Kebudayaan Indonesia. Masmundari (1904-2005) adalah seniman perempuan yang melukis Damar Kurung berdasarkan keterampilan yang diperolehnya secara turun temurun. Di antara banyak lukisan Masmundari, Nyonya Muluk adalah yang paling sering dilukis. Nyonya Muluk digambarkan sebagai perempuan berukuran besar yang mengenakan gaun dan memiliki sepasang sayap. Banyak orang mengatakan bahwa Nyonya Muluk adalah gambaran Ratu Wilhemina yang langsung dilihat Masmundari. Untuk mengungkap identitas Nyonya Muluk, perlu menjelaskan gambar dan makna seni lukis tradisi ini, penulis menggunakan metode Bahasa Rupa (Tabrani, 2012), yang menganalisis isi wimba, cara wimba, tata cara dan cara membaca wimba. Kemudian, dianalisis menggunakan teori postkolonial, khususnya menggunakan konsep hibriditas dan mimikri untuk mengetahui identitas Nyonya Muluk. Akhirnya, penelitian menghasilkan (1) Deskripsi hubungan antara dua budaya (Timur dan Barat/penjajah dan terjajah) yang dimanifestasikan dalam sosok Nyonya Muluk. (2) Nyonya Muluk adalah representasi dari hibriditas perempuan Jawa yang menggambarkan harapan dan impian Masmundari (sebagai perwakilan Timur) untuk menjadi serupa dengan Barat.
\end{abstract}

Kata Kunci: damar kurung, nyonya muluk, perempuan, postkolonial, hibriditas 


\section{INTRODUCTION}

Javanese culture is full of symbols used to teach the wisdom of human life. In particular, about the horizontal relationship between humans and the vertical relationship between humans and God. One form of Javanese culture is art. Art and society have a reciprocal relationship. Social and cultural backgrounds also influence artists in producing art. Social interactions in daily life and transcendent experiences become important backgrounds for artists. Java is one of many Asian countries that use symbolic language to express their thoughts about life. Mythology has an important role in the use of symbolic language. Through mythology, Javanese people understand the Javanese world. Javanese philosophy has many symbols that are manifested in various forms of art. Damar Kurung's paintings are one of Gresik's distinctive cultural artifacts that have recorded many dynamics of civilization through its paintings. Damar Kurung is influenced by Hindu-Buddhist and Islamic culture. Damar Kurung is a distinctive lantern of Gresik which dates back to the 16th century during the Sunan Prapen period (still has a lineage with Sunan Giri). This lantern wrapping paper is decorated with beautiful pictures and has a wise meaning. At first, the Damar Kurung pictures were visually like wayang kulit: full of decorations, distilled and distorted figures, and without perspective. During its development, Damar Kurung's pictures no longer resemble shadow puppets, are simpler and more contemporary but still retain their visual characteristics. The change in style and theme of the Damar Kurung picture cannot be separated from the social context behind it.

Individuals as 'the thinking subject' are actively formulating themselves, formulating their society, and at the same time formulating their place in the face of globalization because of the reasoning system that is owned by each individual. Thus, the social world is treated as the world on the making which will always grow and move according to what is built by the people. Javanese society is a society in which it is loaded with a cultural richness that binds all its members with its reality and symbolic world. Masmundari (1904-2005) as part of Javanese society as well as is a female artist who was active in preserving the Damar Kurung painting tradition. Masmundari painted various themes both spiritual and profane. Of the many paintings she produced, Nyonya Muluk was a figure often painted. Nyonya Muluk is described as a big woman wearing a dress and wings. Around her, there are other human figures in smaller sizes. Who was the figure of Nyonya Muluk and why did Masmundari paint it? The Gresik community knows Nyonya Muluk but does not know who exactly Nyonya Muluk is. Some said that Nyonya Muluk was an angel, and those who thought that it was only a fictional figure of Masmundari. Considering that Masmundari is a painter who always observes first, the writer considers that Nyonya Muluk can't be just a figure of Masmundari's imagination. Based on the results of an interview with Rohayah (74 years), Masmundari's 
daughter mentioned that the figure of Nyonya Muluk painted in Damar Kurung was inspired by Queen Wilhelmina who came to visit Indonesia. Rohayah said that Masmundari was very impressed with the beauty and clothes worn by Queen Wilhemina at that time. So, Masmundari painted it based on her interpretation and creativity into a well-known Nyonya Muluk figure to this day.

Postcolonial theory (Morton, 2014: 101-132) can be said as a theory that can be used as an analytical tool to challenge colonialism practices that are continuing or a new form of colonialism that has given birth to a life filled with racism, unequal power relations, culture subaltern, and hybridity not with war propaganda and physical violence, but dialectically through awareness or ideas. Said (2010:12) says besides a practice, culture is communication and representation, even has aesthetic value. Therefore in line with the thought of cultural differentiation, postcolonialism rejects a monocentric view of human experience, and instead recognizes and values the existence of pluralism and cultural multiculturalism through syncretization and hybridity (Mishra 1993: 41). Pluralism is then defined as a belief, wherein a society consisting of various political, ideological, cultural or ethnic groups, there is not a single dominant group, in which there is an appreciation for differentiation. Identity is expressed through various forms of representation that can be recognized by themselves and others (Barker, 2013:174). Representation by Ratna (2008:123) is interpreted as images and symbols, which traditionally can also be interpreted as similarities and imitations. This shows that the representation is a form of representation, which can replace the true meaning of identity. Further Barker (2009:140) explains that representation is not mimesis, representation is an esthetic expression, a reconstruction of the actual situation. Therefore, Hutcheon (in Ratna, 2008:123) describes all forms of representation, both literal, visual, oral, and cultural in general, both high culture and mass culture, based on certain ideological messages so that they are not free from social and political problems. Representation does not describe a world as it is, but rather builds it. Therefore, this paper aims to see and explain how Masmundari as an East representative made dialectics and negotiations on his identity through images and symbols in the Damar Kurung painting. 

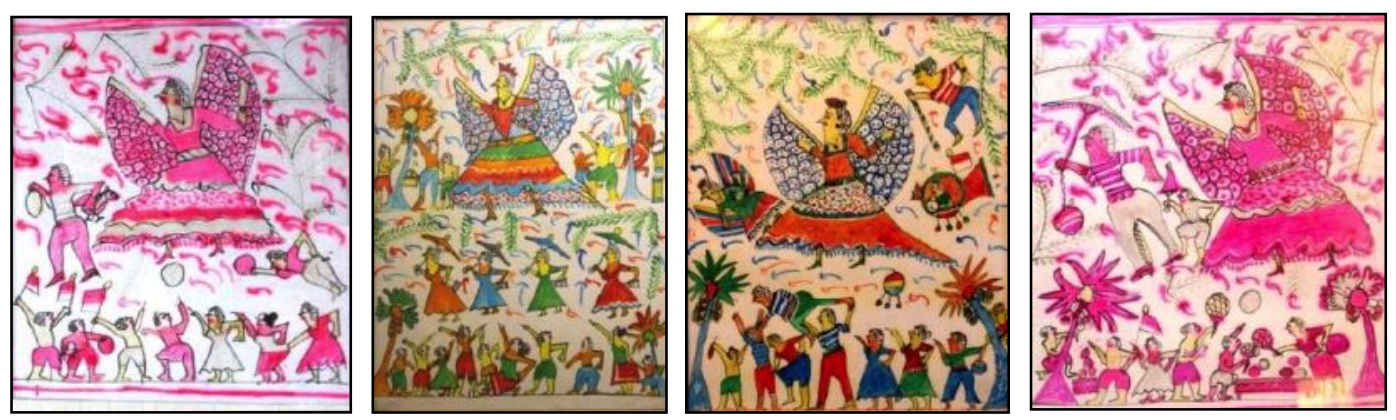

Figure 1. Damar Kurung paintings Nyonya Muluk's Theme by Masmundari

Source: Personal Documentation from Omah Damar Collections, 4th April 2016

\section{Literature Review}

\section{Postcolonial Homi K. Bhabha}

Postcolonial emerged as a study in the 1970s marked by Edward Said's Book of Orientalism (1978), becoming a Western perspective in view of the East. The impact of Orientalism displayed Said is a devastating alienation and psychological marginalization, which between the West and the East will not unite, and give birth to a wider gap. In binary opposition thinking, Lubis (2006:208) says someone is faced with one of the choices "this" or "that" as one that is declared true. For example East versus West, self versus the others, subjectivity versus objectivity, present versus past, observer (subject) versus observed (object) and so on. The binary opposition thinking model places the position of the West, invaders, self, observers, subjects and narratives considered to have superior positions compared to the East, colonized, outsiders, objects, told and so on. As stated by Leela Gandhi (2001:26) that the relationship between colonizers (or former colonies) is a hegemony relationship, colonization as a superior group compared to the inferior colonized parties. The relationship between the colonizers who were hegemonic then gave rise to what was called domination and subordination. Such a pattern of the relationship then brings up unpleasant images of the colonized party as a group of barbarians, uncivilized, stupid, strange, mystical and irrational (Gandhi, 2001:vi), or in the language of Said, the East characteristic is voiceless, sensual, female, despotic, irrational and backward (Said in Moore-Gilbert, 1997:39). Said's thoughts were strongly influenced by the initiators of other theories, such as Michel Foucault, Antonio Gramsci, and other thinkers. Furthermore, postcolonial studies expanded into various fields and developed because of the 'help' of many later generation thinkers. Starting from cultural studies, feminism, visual studies, language studies, and literature. Postcolonialism became a political and theoretical strategy to dismantle the dominance of Western hegemony in line with other worlds. 
The study of postcolonialism applied in this paper is the study of postcolonialism in the thought of Homi K Bhabha. Bhabha initiated the theory of liminality (circumstances or feelings in-between) in the discourse of colonialism. According to Sutrisno and Hendar Putranto (2004: 140-145), Bhabha proposed a liminality model to animate the intersection space between the theory and practice of colonization to give birth to hybridity. This is because the search for identity should never stop. Between the invaders and colonized there is a third space where the crossing of culture or hybridity presents itself in culture, race, language, and so on. Hall asserts that identity is not something rigid with permanent characteristics that do not change from time to time. Identity is something that is constantly formed in the framework of history and culture, something that is positioned at a place and time, according to context. The search for a person's identity is always related to the problem of how that person tries to position himself (positioning) within a scope of society that has placed himself in another sphere (being positioned).

Hybridity refers to the meeting of two or more cultures which then gives birth to a new culture, but the old culture is not abandoned. Hybridity refers to the creation of new trans cultures that exist in the meeting area that is produced through colonization (Ashcroft, et.al., 1998:55). One of the figures in the postcolonial study, Homy Babha, built the definition of hybridity on the foundations of Edward Said and Fanon's ideas (Darmawan, 2014:27). Hybridity begins when the boundaries that exist in a system or culture experience flexing, so that clarity and firmness about things that can be done or cannot be blurred, which ultimately results in a new space. According to Said's Orientalism study, European study trends toward Asia are European-centric and binary opposition. Orientalism refers to the conclusion that colonized people (the East) are silent subjects and under European rule. The meaning of the West over the East is a homogeneous, standard and degrading picture. Whereas Fanon in 'Black Skin White Skin', Babha learned that from the side of the colonized people there was a desire to be the same, as well as fear of the invaders (Darmawan, 2014:27). A separate system which is 'Hybrid', which according to Bhabha is a metaphor for describing the joining of two types (forms) which give rise to certain characteristics of each form, while also eliminating certain characteristics possessed by both. In hybridity, usually, the old identity does not just disappear, although the new cultural identity will strongly influence the old identity. This is where then occurs what is called by Bhaba as the ambiguity of identity that brings someone in a position 'in-between' or 'in the middle' (Rutherford, 1990:211). This is what Bhaba later said that hybridity is a cultural tactic and strategy, where hybrid culture products always avoid all sorts of binary categorization, where hybrid culture products will eventually occupy what is called the third space in each binary category. The interaction between the colonialists was to create a kind of 'acculturation' form that loved and hated, refused but also 
defended. The resistance is not purely tangible as an optional, but it is special, incomplete, and ambiguous, this is what makes the relationship of colonial identity unstable, doubtful, and ever-changing. That interaction results in what is meant as hybridity (through mimicry).

\section{Damar Kurung}

Damar Kurung is a name from 'damar' means 'light' and 'kurung' means cover. Based on function value, Damar Kurung is a lantern that functioned as a room lighting. While the philosophical value is still related to the meaning of 'illuminating' human life in living life. The tradition of painting in Damar Kurung has been made in generations since the 16th century in Sunan Prapen, the third Sunan after Sunan Giri (Koeshanan, 2009). The theme of Damar Kurung painting relating to sacred activities, such as carrying out shalat tarawih, tadarus, Idul Fitri, halal bi halal, macapatan, khitanan, slametan, and others. In its development, the activities of profanity began to dominate Damar Kurung painting, such as night market, bandeng market, a celebration of independence, fishing, birds fishing, cycling, Nyonya Muluk, wedding parties, city building, carnival, and so forth.

In the visual art of Nusantara (including Damar Kurung paintings), always use a system that connects an image with other images to become an interwoven story. Damar Kurung when opened there will be 4 sides of the image. Each side of the image has a different story with the direction to look around. Like other visual art of Nusantara: wayang beber, daun lontar painting, relief of temple, the symbolic concept and its layout always accompanies the pictures therein. Drawing steps on Damar Kurung painting starting from top to bottom for the theme of any story (sacred and profane). Before painting begins, the image field is divided into sections horizontally (usually 2-3 parts). The drawing process starts from the middle to the top image field then moves towards the right. Once the image is finished, go back to the middle of the image first and move it towards the left of the drawing plane. After the image on the left of the image field is complete, proceed to the bottom image field. So on until the entire image field becomes full. In sacred themed paintings such as worship activities, the images are 'read' prasavya (the lantern is rotated to the left, from top to bottom). As for the theme of Profan paintings, such as activities in the market, catching fish or fishing birds, painting 'reads' as pradaksina (Koeshandari, 2014).

\section{Bahasa Rupa}

If in word/verbal language there are word and grammar components, so also in bahasa rupa there is citra and tata ungkapan. Inside the painting, citra can be abstract or representative, Damar Kurung painting included in the category of Representative drawings. A representative image is a pattern of images whose 
visual expression represents the original object so that the shape can be identified (Sunaryo, 2002:107). Depictions of objects in a representative image can be performed in a descriptive, expressive, symbolic and aesthetically pleasing stylus. A representative picture of a narrative describing a situation/event, which is related to the information in conveying it's his messages. Tabrani (2005) uses the term isi wimba for a concrete form of citra that can be touch and feel. Then, cara wimba is how wimba pictured in order to tell a picture. Usually, isi wimba drawn by displaying the object in its entirety (from head to toe), the facial does not exist, but it tends to be of importance to body gestures. That is why the figure of wayang in a state of happiness, sadness or anger, her/his facial expressions remain the same, but her/his posture, hands and head are different.

Stilation image style, where the shape of the drawing object is simplified, is highlighted, altered in such a way that it is not exactly the same as the original object, but the original character can still be preserved. Cara wimba also did through the size of isi wimba. When an object prioritized or becomes the centre of attention, the object is drawn larger than the surrounding object. Cara wimba is a shift of isi wimba. So that all objects are more complete, intact and can be told, without resizing, do not know the perspective. The distant is not minimized or closed by other wimba, but it is shifted upward, therefore the image field becomes full-filled, no empty space. With some background, wimba pictured with layered, overlap, wimba which hang over other wimba means to be far away and declare an event that has happened first.

This research analysis Unit includes the following things:

1. Isi Wimba: Tabrani (2005) uses a wimba content term for a concrete form of viewable and tactile imagery.

2. Cara Wimba: Cara wimba is how isi wimba depicted in order to tell a picture. Covers the image capture size, angle of capture, scale compared to the original object, stilation (stilation, naturalist, expressive), and how it is viewed (pravasya, pradaksina).

3. Tata Ungkapan: Used for a single painting to tell a story. Which includes the dimensions of space, motion, time and emphasis on interests.

\section{METHODOLOGY}

This research uses a constructivist paradigm that orientates on qualitative methods. This means that the study uses constructivist forms by the perspective of various angles based on language (isi wimba, cara wimba, and tata ungkapan). To find a variety of constructed meanings. The constructivist paradigm research model is used to help facilitate the understanding and interpretation of meaning according to the value that is to be achieved. 
Perspective usage of Bahasa Rupa especially RWD System (Ruang-WaktuDatar) (Tabrani, 1991). Based on consideration because of the traditional artwork in Nusantara (The East) more precisely reviewed using $R W D$ perspectives rather than NPM (Naturalis-Perspektif-Momenopname) which is widely used for Western fine arts (since the Renaissance era). $R W D$ system shows how to draw from various directions, various distances and various times. In the $R W D$ system, a sequence is drawn consists of a number of scenes and moving objects in an image field (space). Thus the RWD system has space and time dimension. The results of the interpretation of language and symbolically Damar Kurung painting about Nyonya Muluk, then analyse the postcolonial theory of Homi K. Bhabha to find out the symptoms of mimicry and hybridity inside.

\section{DISCUSSION}

\section{Nyonya Muluk's Identity}

Binary opposition is important in post-colonial studies because the West is trying to make a clear distinction from the East. The analysis showed that Javanese women (as the East representatives) were distinguished from Western women based on their physical appearance. Nyonya Muluk's identity as a Western woman is described as a woman wearing a colorful fancy gown, crown, jewelry (necklaces and earrings) and high heels. The difference is very clear compared to Javanese women who wear kemben/kebaya kutu baru, jarik, hair in a bun, without jewelry and barefoot.

Damar Kurung's paintings are folk art that is drawn spontaneously, honestly, and simply by Masmundari. Rohaya, Masmundari's daughter said that she always draws without being preceded by a sketching process. An interesting experience for him will be directly drawn on paper and she will not stop before the painting is finished. Even if she spends all day, Masmundari will not eat or bathe until the painting is finished. Now Damar Kurung's paintings no longer belong to Masmundari individually, but they belong to the Gresik community as a whole because each of his works reflects the socio-cultural background in Gresik. Masmundari painted Nyonya Muluk and other women based on certain considerations. Masmundari as a woman born from Javanese culture upholds the philosophy of life: "ajining dhiri saka pucuke lathi, ajining raga saka busana" (Achmad, 2017:107). Meaning: a person's self-esteem depends on their words, their self-esteem depends on the clothes they wear. Javanese people have the principle to maintain the harmony of clothing by following self-identity. Clothes that make themselves valuable do not have to be fancy, expensive and colorful. Because the clothes are not necessarily appropriate and in harmony with their identity as Javanese. From studying the images of Nyonya Muluk it was found that the scene 
took place outside, on the Gresik beach which tends to be hot. The incompatibility of the dress worn by Nyonya Muluk and the location proves that Nyonya Muluk is a foreigner/stranger. While the kemben, jarik and hair bun worn by a Javanese woman adjusts where she lives with the hot atmosphere typical of the tropics. Clothing and attributes used not only reflect cultural identity, but also geographical identity.

Table 1: Table of Meaning Analysis: Bahasa Rupa and Symbolic

\begin{tabular}{|c|c|c|}
\hline ISI WIMBA & CARA WIMBA & TATA UNGKAPAN \\
\hline Nyonya Muluk & $\begin{array}{l}\text { - } \text { From head to toe } \\
\text { - Head side view } \\
\text { - Front body } \\
\text { - Wearing dress, high } \\
\text { heels, necklace, earrings } \\
\text { and lipstick } \\
\text { - Pointed/sharp nose, curly } \\
\text { hair } \\
\text { - There are wings } \\
\text { - Static gesture } \\
\text { - Giant size }\end{array}$ & $\begin{array}{l}\text { - } \text { Naturalist stilation } \\
\text { - Larger size stated the } \\
\text { importance } \\
\text { - There is a bottom } \\
\text { edge of the landline } \\
\text { - Scratches of arrows } \\
\text { indicate movement } \\
\text { (air circulation } \\
\text { outside the room) }\end{array}$ \\
\hline Other women & $\begin{array}{l}\text { - From head to toe } \\
\text { - Head side view } \\
\text { - Front body } \\
\text { - Wearing kemben/kebaya } \\
\text { - } \text { kutu baru and jarik } \\
\text { - Hair bun } \\
\text { - Dynamic gesture } \\
\text { (pointing, carrying a } \\
\text { - } \text { flag/something else) } \\
\text { - Barefoot }\end{array}$ & $\begin{array}{l}\text { - Naturalist stilation } \\
\text { - Smaller size stated } \\
\text { unimportant } \\
\text { - There is a bottom } \\
\text { edge of the land }\end{array}$ \\
\hline Man & $\begin{array}{l}\text { - From head to toe } \\
\text { - Head side view } \\
\text { - Front body } \\
\text { - Wearing plain shirts, } \\
\text { white-red striped shirts } \\
\text { (from Madura), shirtless } \\
\text { and wearing shorts }\end{array}$ & $\begin{array}{l}\text { - Naturalist stilation } \\
\text { - Smaller size stated } \\
\text { unimportant } \\
\text { - There is a bottom } \\
\text { edge of the landline } \\
\text { - Scratches of arrows } \\
\text { indicate movement }\end{array}$ \\
\hline
\end{tabular}


- Dynamic gesture (pointing, carrying a flag/something else)

- Barefoot (air circulation

outside the room)

The colonized side thought that the invaders were a great, strong, rich people who could change the poverty of one's life. Postcolonial born to sue the colonial construction that has oppressed marginal groups. Postcolonial then dismantled (deconstructed) structured discourses, including in mapping politics and power. There are two main topics of discussion of postcolonial criticism, namely the issue of language and identity. The problem of identity is related to the problem of hybridity, namely the problem of national identity that changes due to the cultural influence of the colonial nation, including mimicry (the act of imitating colonial culture) by colonized.

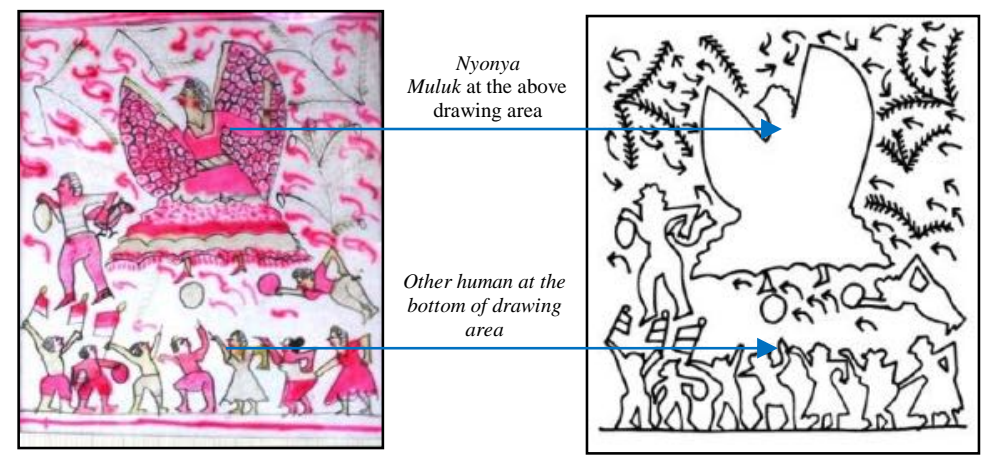

Figure 2. Nyonya Muluk (The West) at the above of drawing area and other humans (The East) at the bottom of the drawing area.

Said (1998:7) shows that the Western world gains its strength and identity by relying on the East. The identification of the East by the West is part of the West's attempt to identify itself as superior in many ways. The relationship between invaders and colonizers (former colonies) is hegemonic, the invaders as a superior group compared to the inferior colonized parties, and from the relationship between hegemonic invaders and then came the so-called domination and subordination. Analysis of how to draw in the figure of Nyonya Muluk Damar Kurung shows differences in a human size, scale with original objects, body movements and the direction of vision of the wimba. Nyonya Muluk as a reflection of humans from the West is described in larger size compared to other human sizes. The static gesture shows a stable and solid strength. Unlike other human figures, which are drawn in smaller sizes, gestures are more open and dynamic, in an upward-looking position, pointing at Nyonya Muluk. Both are drawn in different positions: Nyonya Muluk (West) above the drawing plane and another human (East) at the bottom of the drawing area. The size and position of the wimba show a model of binary opposition 
thought that places the West as a colonizer in a superior position compared to the colonized East. From such a relationship pattern arises unpleasant stereotypes about the colonized party as a low, stupid and irrational group. Described as people who are not dressed and barefoot.

\section{The Hybridity of Nyonya Muluk}

Nyonya Muluk comes from the word 'Nyonya' which means the nickname of an older/more respected woman. 'Muluk' in Javanese and Indonesian (KBBI) means to soar. Nyonya Muluk is described as flying because she has a pair of wings. Nyonya Muluk in Damar Kurung, which is a traditional archipelago art, cannot be separated from the cultural philosophy behind it. Wings in Javanese culture have been widely used, both in the past and in the present. Such as Gurdo batik motifs, mythological animals in temple reliefs in Central and East Java, the symbol of the Ngayogyakarta Hadiningrat Palace, the symbol of Indonesian education and culture: Tut Wuri Handayani, to the symbol of the Republic of Indonesia: Garuda Pancasila. According to Javanese philosophy, wings or 'suwiwi' or 'lar' has the meaning as "Swiwi Peksi, lambange gegayuhan inggil kayadene sumundul angkasa" (Achmad, 2017), which means symbolizing high ideals, as high as the sky.

Masmundari described it in an open and symmetrical wing, identical to the classic Gurdo batik motif. The shape of the Gurdo motif consists of two wings and in the middle, there is a body and a tail. Inspired by Garuda (Hindu animal mythology). Garuda is a mythological animal ridden by Lord Vishnu. By the Javanese, Garuda is not only a symbol of life but also as a symbol of virility and strength (Atmojo, 2011). On the wing of Nyonya Muluk there is a decoration that has similarities with batik isen-isen. Isen-isen is an element of decoration in batik. Isen-isen can be a point, line, or a combination of both. Of the various types of $i$ senisen, found in the wings of Nyonya Muluk is a type of scales (fish-point scales). The decorations are like fish scales in the middle of which have black dots. Made repeatedly and cross each other. This isen-isen is an ancient motif that already existed in the XIV century mentioned in the book Pararaton (Atmojo:2011). Isenisen reflects hope for strength and longevity.

Identity is also presented by Hall as a thing that is always changing and never permanent. Therefore, a person can experience a change of identity along with his life. Cultural identity here then contains political identity, namely the politics of positioning in certain societies. Implicitly, Bhaba (in Sutrisno et al. Ed, 2004: 145-146) also argues that cultural identity is not an innate identity carried from birth to emptiness. Cultural identity is not a predestined entity. The views of binary opposition 'invaders' and 'colonized' are no longer separate from each other and stand-alone. On the contrary, Bhaba's opinion suggests that the negotiation of 
cultural identity includes the continuous encounter and exchange of cultural views which in turn will result in mutual recognition of cultural differences. According to Bhaba, culture and cultural systems are formed in the third space. That interdependence takes face in hybridity. Identity hybridity, manifesting itself in culture, language, race and so on. Based on the above view, Masmundari defines identity as an 'entity' that can be changed according to specific history, time and space, moreover, paintings have free characteristics in producing symbols and meanings. The concept of cultural identity is closely related to communication events that use signs and symbols of communication. Therefore, how the Gresik people interpret the symbols in the Damar Kurung painting at the level of communication can also be interpreted as a cultural identity.

It is in this hegemonic pattern of relations that the colonized people find a strategy of resistance to the domination of colonial discourse. Not against in a frontal way, but with the 'cross-culture'. So they began to imitate the invaders in dress and behavior. This act of imitation is called mimicry. Mimicry is not only a process of imitation but also a form of subversive resistance. From his subconscious, Masmundari portrays Nyonya Muluk by combining conflicting cultural elements, which reflect a postcolonial subject that is never perfect. The ambivalence that arises from a reciprocal point of view shows a form of negotiation or resistance from a colonized position. In of Mimicry and Man: Ambivalence of Colonial Discourse (Bhabha, 1994: 85-92), Bhabha defines mimicry as almost the same subject, but not completely created by the colonized parties to be similar to the colonialists. Mimicry is a sign of dual articulation, a complex strategy of renewal, regulation, and discipline. If Rohayah, Masmundari's daughter states that Nyonya Muluk is Queen Wilhemina seen directly by Masmundari, then the truth needs to be criticized. Based on the findings of Nyonya Muluk's visual data and all the surrounding attributes it can be concluded that Nyonya Muluk is not entirely a Western or Eastern woman. Rohayah assessed that Nyonya Muluk was a reflection of Masmundari's fascination (as well as modesty) when she saw Queen Wilhemina in person. Queen Wilhemina who was present with a beautiful dress and a relatively large body for the Caucasian group caused Masmundari to feel inferior. Masmundari's cultural background as a Javanese person contributed to the creative process of creating Nyonya Muluk. The symbols commonly used in Javanese culture to convey meaning implicitly are used by Masmundari to complement the figure of Nyonya Muluk. Javanese who tend to maintain harmony in life always use symbols/figures of speech to convey meaning never conveyed in a frontal manner. Masmundari wants to identify himself with the invaders who are higher, more beautiful, superior in all respects. Masmundari's imitation and integration of Western and Eastern elements was a form of resistance to the colonialism she experienced. It is worth remembering again that Masmundari was born in 1904 and 
died in 2005, meaning she has the experience of first hand a period of Dutch and Japanese occupation.

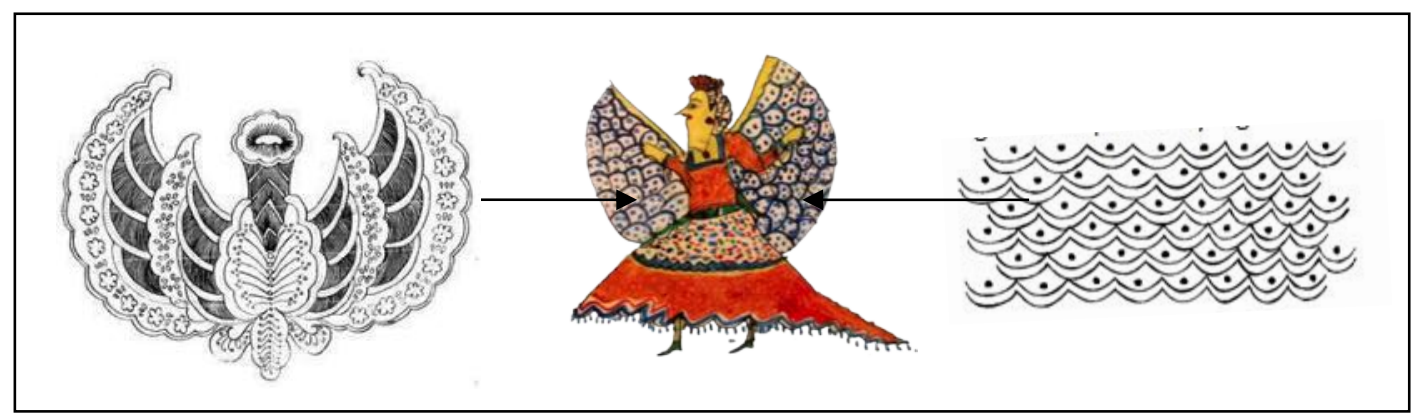

Figure 3. Gurdo motif batik, isen-isen sisik melik and Nyonya Muluk's wings

\section{CONCLUSION}

Bhaba added that postcolonial not only created hybrid culture or practice but also created new forms of resistance and negotiation for a group of people in their social and political relations (Bhaba, 2004: 113-114). Hybridity also allows for the introduction of new forms of identity production and cultural forms. So hybridity can be accepted as a tool for understanding cultural change through strategic termination or temporary stabilization of cultural categories (Barker, 2005: 210). Bhabha (1994: 84-92) finds 'mimicry' as proof that the colonized are not always silent, because they have the power to resist. Masmundari, as a representative of the colonized Eastern people, tried not to stand still, she made a 'fight' through the paintings she produced. The concept of mimicry is used to describe the process of imitating or borrowing various cultural elements. Mimicry does not show the dependence of the colonized on the colonized, but imitators enjoy and play with the ambivalence that occurs in the imitation process. Thus, mimicry can be seen as a strategy to confront colonial domination. Like disguise, it is ambivalent, perpetuating but at the same time emphasizing its dominance. (Martono, 2013: 125126). This mimicry shows that it is the basis of a hybrid identity (Moore and Gilbert 1997: 55).

Each artwork reflects the community setting in which the artwork was made. Artists always come and live from the community. Life in society is a reality that is directly encountered as a trigger for creativity. In facing the stimulation of its creation, artists can take a position as public witnesses or can also be a critic of the community. In this case, artists are free from the values held by the community. Although the artist lives in a society with his values and learns with these values, he also has the freedom to agree or disagree with the values of that society. Masmundari as part of Javanese society does her job as an artist who expresses his assessment of the socio-cultural situation that occurs around her. No matter how 
imaginative artwork is, artists always start from the concrete conditions of society. Masmundari is an artist who is sensitive to detect irregularities that occur in social life. Besides, Masmundari lived at the age of more than a century, she experienced the period of Indonesia being colonized by the Dutch and Japanese. The dynamics of the lives of colonized people were immediately felt by Masmundari.

The figure of Nyonya Muluk in Damar Kurung is a manifestation of Masmundari's creative process in responding to the phenomena that occur around her. Nyonya Muluk is said as a picture of Queen Wilhemina seen directly by Masmundari. Improvements made by Masmundari in creating the figure of Nyonya Muluk showed that there was a merging of symbols from the West and East. Nyonya Muluk also illustrates the hopes and dreams of Masmundari (as the East representative) to be similar to the West, even though it was not the same.

\section{REFERENCES}

Achmad, Sri Wintala. (2017). Asal Usul dan Sejarah Orang Jawa. Yogyakarta: Penerbit Araska.

Atmojo, Wahyu Tri. (2011). Barong dan Garuda dari Sakral ke Profan. Yogyakarta: Pascasarjana ISI Yogyakarta.

Barker, Chris. (2013). Cultural Studies, Theory and Practice. Yogyakarta: Kreasi Wacana.

Bhabha, Homi. (1994). The Location of Culture. London, New York: Routledge.

Bhabha, Homi. K. (1995). Cultural Diversity and Cultural Differences, in Ashcroft, B., et.al (eds). The Postcolonial Studies Reader. London. Routledge.

Darmawan, Darwin. (2013). Tesis: Identitas Hibrid Orang Cina Indonesia Kristen: Ketegangan dan Negosiasi antara Kecinaan, Keindonesiaan, dan Kekristenan. Yogyakarta. Universitas Gadjah Mada.

Gandhi, Leela. (2001). Teori Poskolonial: Upaya Meruntuhkan Hegemoni Barat (terj). Yogyakarta: Penerbit Qalam.

Koeshandari, Ika Ismoerdijahwati. (2009). Damar Kurung dari Masa ke Masa. Surabaya: Dewan Kesenian Jawa Timur.

Koeshandari, Ika Ismoerdijahwati. (2014). Budaya Nusantara melalui Damar Kurung: Analisis Bahasa Rupa. Jurnal Budaya Nusantara Vol.1 No.1 Tahun 2014. Surabaya: Universitas PGRI Adi Buana Surabaya.

Lubis, Akhyar Yusuf. (2006). Dekonstruksi Epistemologi Modern. Jakarta. Pustaka Indonesia Satu.

Mishra, Vijay, Bob Hodge. (1993). What is Post Colonialism dalam Colonial Discourse and Post-Colonial Theory? Textual Practise, 1991. London: Harvester Wheatsheaf p.41. 
Mishra, Vijay. (2007). The Literature of the Indian Diaspora Theorizing the Diasporic Imaginary. London: Routledge.

Morton, Stephen. (2014). Gayatri Spivak: Ethics, Subalternity, and the Critique of Post-Colonial Reason. Cambridge: Polity Press.

Ratna, Nyoman Kutha. (2008). Postkolonialisme Indonesia. Yogyakarta. Pustaka Pelajar.

Said, Edward. (2010). Orientalisme (Menggugat Hegemoni Barat dan mendudukkan Timur Sebagai Objek). Yogyakarta: Pustaka pelajar.

Said, Edward. (1998). Peran Intelektual (tras.). Jakarta: Yayasan Obor Indonesia.

Sunaryo, Aryo. (2002). Seni Rupa Nusantara Pengantar Kajian dan Apresiasi Seni. Semarang: Dahara Prize.

Sutrisno, Mudji; Hendar Putranto. (2004). Hermeneutika Pascakolonial: Soal Identitas. Yogyakarta: Penerbit Kanisius.

Tabrani, Primadi. (1999). Belajar dari Sejarah dan Lingkungan, Sebuah Renungan Mengenai Wawasan Kebangsaan dan Dampak Globalisasi. Bandung: Penerbit ITB Bandung.

Tabrani, Primadi. (2005). Bahasa Rupa. Bandung: Penerbit Kelir. 